\title{
The Role of Leadership Style in Fostering Creativity in the Workplace
}

\author{
Hardiani $^{1}$ and Muhammad Tafsir ${ }^{2}$ \\ ${ }^{1,2}$ Department of Management, STIEM Bongaya, Makassar City, Indonesia \\ Email address: \\ hardianiliyusuh@gmail.com
}

\begin{abstract}
The success of a business in the face of competition is inextricably linked to the ability of a transformational leader to foster a climate of creativity in the workplace. This study presents the findings of an analysis of the role of transformational leaders in fostering a climate of creativity in organizations. Multiple regression analysis is used to analyze data collected from respondents who are randomly selected from employees at several companies and then processed using the SmartPLS application. The researcher developed an instrument for the variables transformational leadership and climate of creativity based on several instruments used in previous research. The findings indicate that there is a strong correlation between transformational leadership and a climate of creativity, implying that transformational leadership plays a critical role in fostering creativity in the workplace.
\end{abstract}

Keywords: Transformational Leadership Style, Workplace, Climate of Creativity.

\begin{abstract}
Abstrak: Keberhasilan perusahaan dalam menghadapi persaingan bisnis tidak lepas dari kemampuan seorang pemimpin transformasional untuk menciptakan iklim kreativitas di lingkungan kerja. Penelitian ini mengungkapkan hasil analisis dari peran pemimpin yang memiliki gaya kepemimpinan transformasional dalam membangun iklim kreativitas pada perusahaan. Metodologi yang digunakan adalah analisis regresi berganda, yaitu menganalisis data yang dikumpulkan dari responden yang berasal dari karyawan di beberapa perusahaan yang dipilih secara acak yang kemudian diolah menggunakan aplikasi SmartPLS. Peneliti mengembangkan instrumen yang digunakan pada variabel kepemimpinan transformasional dan iklim kreativitas dari beberapa instrumen yang telah digunakan pada beberapa penelitian sebelumnya. Hasil menunjukkan bahwa ada hubungan yang erat antara kepemimpinan transformasional dan iklim kreativitas, hal ini menunjukkan bahwa kepemimpinan transformasional memiliki peran penting untuk mengembangkan kreativitas pada lingkungan kerja.
\end{abstract}

Kata Kunci: Gaya Kepemimpinan Transformasional, Tempat Kerja, Iklim Kreativitas.

\section{INTRODUCTION}

Today's market climate requires companies to revitalize existing goods and services to keep up with rapidly evolving consumer demands. Innovative concepts, goods, and services have positioned themselves as sources of competitive advantage and market opportunities. Regardless of industry, product and service innovation has become a critical 
factor in determining a business's long-term performance (Hon, 2012). Businesses that offer only dated products and services may perish, especially in developing countries, where innovation is constantly emphasized (Hon, 2012). As a result, creativity has become a critical component of adapting to the rapidly evolving global business climate. According to research, the service sector accounts for more than $70 \%$ of developing country's gross domestic product (GDP). The environment in which organizations operate is becoming more dynamic and complex, organizations must be more creative and innovative to survive and thrive in this environment (Hong et al., 2012). Human resources in organizations can be used to aid in the achievement of goals, both individually and collectively. To accomplish an organization's vision, mission, and goals, both leaders and employees must contribute. Organizations fuel practitioners' and academics' efforts to identify factors that promote creative behavior in groups and organizations (Bass et al., 2003). In this regard, leaders compete to motivate employees to optimize their creative thinking to generate ideas and creative thinking to compete against the company's competitors.

It thus plays a critical role in propagating and consuming innovation and creativity (Ostrom et al., 2010). Talking about problems or successes in a company cannot be separated from the role of a leader. Several factors largely determine the success or failure of a company to achieve its goals, and one of them is the role of a leader (Bass et al., 2003). (Nasir et al., 2021) A leader's image has a significant impact on employee behavior in carrying out tasks and improving employee performance; additionally, a leader's role is to unite the organization and to control and shape employee attitudes and behavior. The ability of a company to achieve business and public-oriented goals will always be a reflection of the success or failure of a leader. In terms of its importance in company success, the issue of leadership is an exciting issue to be studied by researchers in organizational behavior. In an organization, a leader has a considerable influence. A leader plays an essential role in formulating and running the company. (Schein, 1992; Nahavandi and Malekzadeh, 1993; (Su'ud, 2000). (Amabile, 1996); (Mumford and Gustafson, 1998); (Jung et al., 2008) found that leadership is one of the factors driving innovation. Transformational leadership style can make subordinates work beyond their interests by changing the values and self-concept of subordinates to increase the needs and aspirations of employees (Janseen, 2003); (Khasanah and Himam, 2018). A leader who demonstrates transformational leadership can influence his employees by expanding and increasing goals. Transformational leadership raises employees' performance expectations (Bass, 1995) and aims to alter followers' values and self-concepts to move them toward higher levels of aspirational needs (Jung, 2001). Motivating employees aims to instill confidence in them so that their performance can exceed the company's expectations. According to (Nardo et al., 2018), transformational leadership had no significant effect on the innovative behavior of company employees. The test results indicate that transformational leadership does not directly contribute to employee innovative behavior. While respondents' level of achievement for transformational leadership variables is satisfactory, this does not imply that transformational leadership directly contributes to employee innovative behavior.

Thus, to establish a sound business structure, a company must encourage its workers to be innovative (Nieves et al., 2014). Leaders place a premium on cultivating innovation in their workers to achieve creative results. According to (Shalley and Gilson, 2004), employee innovation is influenced by both human characteristics and the environment in which they 
function. Similarly, prior research has uncovered many predictors of employee creativity. Researchers of creativity have discovered that leaders can have a significant contextual effect on employee success, resulting in creative and innovative outcomes (Shalley and Gilson, 2004). It has been researched as a leadership style for supervisors (Wang et al., 2014). For instance, (Amabile et al., 2004) reported that leader behavior is a critical factor in determining an individual's creativity in the work environment. Additionally, individuallevel variables contribute significantly to employee creativity (Sun et al., 2012). Both methods are used in this study to develop a systematic model for forecasting employee innovation. To foster innovation and creativity, organizations must be led by leaders capable of resolving complex challenges through creative solutions (Williams and Foti, 2011). Recent research on creativity has identified transformational leadership as a significant predictor of employee creativity see (Wang et al., 2014). The expectation is that creative performance will occur as a result of a transformational leadership style that fosters proactive employees through intellectual stimulation, inspirational motivation, idealized influence, and individual consideration. The moderating variable was chosen to be the transformational leadership style because it is more effective at responding to change (Bass, 1995). Additionally, transformational leadership is more effective at influencing and encouraging employees to generate creativity-in comparison to transactional leadership (Herrmann and Felfe, 2013). For instance, transformational leadership fosters an environment conducive to creativity (Bass et al., 2003) and mobilizes the contextual resources required for subordinates to engage in innovative conduct. However, very few studies have been conducted in India on the topic of creativity. (Gupta and Singh, 2013), for example, discovered an important effect on the creativity of leader workers. Thus, through transformational leadership behaviors such as inspirational encouragement, intellectual stimulation, idealized power, and individual considerations (Bass et al., 2003), a transformational leader may easily meet subordinates' needs and inspire them to work creatively (Gupta and Singh, 2013).

The innovation process is frequently initiated by an opportunity to discover an opportunity, a problem that arises, or a puzzle that needs to be solved. Exploration of the opportunity may include identifying ways to improve the current service or delivery process or attempting to think differently about the work process, product, or service. (Setyowati and Etikariena, 2019). Individuals' creativity, aided by the development of their knowledge, intellectual abilities, thinking styles, motivations, personalities, and environment, results in innovations that emerge from new ideas, new conversations, new desires, and new research. Because creativity is a catalyst for the emergence of innovative ideas that contribute to a company's success, businesses must encourage their employees to generate creative ideas and then develop them, so that their creativity becomes a competitive advantage. (Aprilliyani, 2006) At work, innovation can come from new ideas generated by employees or from those obtained from business partners, friends, and managers.

After that, there is the process of conveying the concept to others. If the idea can be implemented and approved, the preparation stage for implementation can begin. Apart from recognizing opportunities, the ability to develop new ways to capitalize on those opportunities is critical for innovation. The term "idea generation" refers to the process of developing concepts with the intent of improving. The ideas generated can be for new products, services, or processes, for entering new markets, for improving current work 
processes, or for solving identified problems in general (Setyowati and Etikariena, 2019). (Jaiswal and Dhar, 2015); (Masro, 2020) demonstrates that the innovation climate plays a significant role in mediating the relationship between transformational leadership and employee creativity. In his study, he discovered a relationship between the effect of innovation climate at the group level and employee creativity. Transformational leadership can more effectively engage their employees in creative behavior if the organization fosters an environment conducive to innovation. This demonstrates that when individuals perceive sufficient support for innovation in terms of resource availability, motivation, and recognition within the organization, they perform better in terms of creativity.

Transformational leadership has a positive effect on employees' willingness to change because it emphasizes exemplary and influence dimensions. Additionally, briefings and meeting sessions frequently held by leaders can help raise employee awareness and a strong belief in their ability to change to maintain their continuous performance. The motivation provided by transformational leaders instills confidence in the organization's ability to perform better in the future because it can see new opportunities (Asbari et al., 2021). However, (Makena, 2017) revealed that these findings indicate that having a leader who behaves well as a transformational leader and supports all employee activities does not always help an employee work better. either to foster innovation or to generate new ideas that are required. The more transformational leadership is used, the less likely it is that innovation will occur. (Mustika, 2017) The presence of a transformational leader has no discernible effect on the creativity of proactive employees. In terms of respondent characteristics, the leader's role is insignificant due to the length of service in the current position. This is because employees become more acquainted with and knowledgeable about their jobs. Employee expertise and experience result in a reduction of the leadership role (e.g. in terms of support and direction).

Additionally, evidence demonstrates that an environment conducive to innovation motivates workers to work at a higher degree of creativity (Wang et al., 2014). Nonetheless, the scant literature on innovation environment has advanced our understanding of the precise position of innovative climate at various levels, thus constraining our understanding of innovation climate as a multilevel phenomenon (Wang et al., 2014). Recent multilevel studies have revealed a positive correlation between individual creativity and group-level variables such as leadership style, supportive colleagues, and encouragement for innovation (Hon, 2012). (Chen et al., 2013). These continuing results emphasize the critical nature of considering the innovation environment at several levels. However, due to the breadth of the definition of innovation environment, few studies have discussed cross-level questions, such as whether group climate motivates individual creativity (Wang et al., 2014). Additionally, previous research has discovered that employees' creative self-efficacy profoundly affects their individual creative actions (Gong et al., 2009) discovered a major mediating function for creative self-efficacy in predicting employee innovation in their research. (Bandura, 2002), on the other hand, has emphasized the reciprocal relationship between innovative activity and self-efficacy.

When we discuss creativity, we are referring to innovation; however, there is a distinction between creativity and innovation. Creativity is characterized by the development of ideas that are novel, unique, relevant, and useful to the organization. Meanwhile, innovation is the process by which new ideas are implemented by company 
employees (Zhou and George, 2001). A business's innovation process begins with creative ideas. According to the findings of (Azliyanti et al., 2019), transformational leadership does not affect individual creativity. According to (Bandura, 2002) social cognitive theory, transformational leadership is a critical external factor in employee learning. Transformational leaders engage employees in intellectual stimulation, establish standards for creativity, and assign employees creative roles. Employees tend to attend and learn from transformational leaders because they are charismatic and inspiring. The results of the study (Wulansari, 2016) indicated that transformational leadership did not affect individual creativity when a path analysis test was used to examine the relationship between transformational leadership and creativity. Additionally, it was discovered through interviews with company leaders that employee creativity emerges spontaneously when there are work-related problems. These issues encumber the work to the point where employees take the initiative to generate ideas that will lighten their load. When employees generate ideas, the first permit the foreman, who then submits them to the supervisor, who then submits them to the manager for final approval or rejection.

This research will contribute to literacy and managerial practices by illustrating the multilevel impact of group-level variables on individual-level variables to enhance creative efficiency. This study hypothesizes that the group supervisor's transformational leadership behavior fosters a favorable view of the group's innovation environment among followers, encouraging them to appear innovative. The results of this study will guide managers who are constantly devoting organizational and financial resources to fostering employee innovation. The following section discusses the theoretical foundations for hypothesis creation, followed by testing methods, data analysis, and conclusions. Finally, we address the study's consequences, findings, and limitations.

\section{THEORITICAL REVIEW}

Researchers have characterized the atmosphere of innovation in a variety of ways (Cooke and Rousseau, 1988). However, it is widely believed that the atmosphere of innovation is expressed in people's perceptions of success or assumptions about environmental characteristics that influence expectations about job outcomes and interactions (Parker et al., 2003). Thus, unlike culture, the climate is a local phenomenon representing both individual and group-level environmental pressures (Hunter et al., 2007). Frequently asked questions about the organizational environment of innovation, such as whether "employees feel free to share their boss's thoughts" or whether "people here are not afraid to take risks." As shown by these queries, the climate is regarded as a domainreference phenomenon (eg, climate for creativity, climate for service). The climate of creativity, innovation, and change are described as the environment that enables an individual to develop an idea or make a quantum leap of thinking in response to specific challenges or opportunities (Creative Problem Solving Group, 2002).

(Natsir, 2004) proposes that transformational leadership refers to a leader's or superior's influence over subordinates. Subordinates have a sense of trust, pride, loyalty, and respect for their superiors, and they are motivated to go above and beyond the call of duty. Transformational leadership must be able to articulate a clear vision for the organization for followers to accept the leader's credibility" (Su-Yung, 2002). According to 
(Bass et al., 2003), "the primary function of a transformational leader is to serve as both a catalyst and a controller of change." According to (Case, 2003), while there are some distinctions in how transformational leadership is defined, they all interpret it as an agent of change.

The value of employees who consistently demonstrate creativity, innovation, and change within the company is one of the primary factors contributing to a healthy environment of creativity. (Kazama et al., 2002) reminded us that the primary impediment to handling creativity and innovation is inattention management. To foster innovation, leaders must first create an environment conducive to it. Van de Ven continued by stating that workers create habits, which makes them less flexible in their thought and actions and prevents them from feeling the need to adapt. (Scott and Bruce, 1994), (Kazama et al., 2002) assert that leader activity based on the Leader-Member Exchange (LMX) theory can be used to forecast the environment of innovation. More precisely, the more positive the interaction between leaders and subordinates is, the easier it is to foster a creative work environment. The study of environmental factors affecting work has been grouped under the umbrella term "climate" (Patterson et al., 2004). As (Ekvall and Ryhammar, 1999) described, the climate is a feature of organizational life that consists of behaviors, behavioral styles, and measurable and repetitive feelings. According to (Patterson et al., 2004), the climate is a common understanding of individual perceptions of policies, activities, and organizational procedures. To be more precise, the organizational environment is self-contained within the company and reflects employees' perceptions of a strategic focus area or organizational role (Parker et al., 2003). A study of the literature reveals a high level of interest in a specific climate focus, such as the ethical climate (Wimbush et al., 1997), the service climate (Tsai and $\mathrm{Wu}, 2001$ ), or the procedural justice climate (Naumann and Bennett, 2002).

The climate of creativity theory has attempted to characterize aspects of the work environment that foster creativity, especially from an organizational or business perspective (Amabile et al., 2018). According to (Ekvall and Ryhammar, 1999), the environment for innovation is one of struggle, independence, and help. Similarly, innovation fosters employee transparency and shared understanding in the face of uncertainty. (Amabile et al., 2002) describes that the contextual component is critical for fostering an environment of creativity in the workplace. This component includes the urge to be creative, independence in exploration, autonomy, staff, strain, and barriers to creativity posed by organizations or businesses. Numerous theoretical mechanisms have been used to identify variables affecting creativity that can influence creative achievement. For instance, Amabile's (Hunter et al., 2007) creation theory of intrinsic motivation employs an eight-dimensional model that includes group support work, demanding work, national drive organization, supervisory drive, organizational obstacles, freedom, workload strain, and inadequate resources. Meanwhile, (West et al., 2003) developed four dimensions based on team interaction theory: participatory protection, creativity support, challenging goals, and task orientation. (Isakson and Lauer, 2002) developed a dispositional model based on psychological theory, resulting in nine dimensions: confidence and openness, cheerfulness and commitment, discussion, independence, risk-taking, idea support, idea timing, and conflict. Other models of creativity's climate component are focused on organizational reinforcement methods, environmental evaluation, commitment (Mossholder and Dewhurst, 1980), new product creation criteria, and organizational learning theory (Hunter et al., 2007). 
(Burns, 2004), a presidential biographer and leadership expert, coined the term "transformational leadership" for the first time. It defines transformational leadership characteristics as when a leader and his subordinates collaborate and encourage one another to boost morale and motivation (Guns, 2020). In recent years, Bernard M. Bass expanded on Burns's theories by presenting his transformational leadership theory. According to (Bass, 1985; Guns, 2020), transformational leadership can be characterized by its effect on followers. Bass advises transformational leaders to earn their followers' confidence, respect, and admiration. Leadership transformation has been conceptualized as a multidimensional phenomenon (Bass, 1985; Guns, 2020). (Bass et al., 2003) suggested a more fitting definition of transformational leadership in their research, one that incorporates inspirational motivation, individual consideration, intellectual stimulation, and idealized power. Through the use of idealization, the leader encourages followers' innate thoughts by serving as role models and earning their love, admiration, and loyalty, resulting in the sense of community among followers. According to (Guns, 2020), leadership in the transformation model is described as a leader who constantly inspires his subordinates to make positive changes. Energetic, passionate, and enthusiastic are characteristics of a transformational leader. A transformational leader will often prioritize assisting subordinates in achieving success. Additionally, the leader will still be concerned and will make an effort to be involved in the work process (Guns, 2020).

Four primary characteristics define a leader with a transformational Bass style (Guns, 2020). Intellectual stimulation is comprised of four elements. A leader with a transformative style is constantly attempting to stimulate his subordinates' imagination by providing opportunities for continuous learning and avoiding the status quo. Additionally, transformational leadership entails providing assistance and motivation to individual followers. To cultivate trusting partnerships, transformational leaders maintain open lines of communication, encouraging followers to share their perspectives. The leader should immediately acknowledge each follower's distinct contribution. Inspirational Motivation: Transformational leaders possess a compelling vision that they are capable of communicating to their followers. These leaders will also inspire followers to share their enthusiasm and inspiration for accomplishing these goals. Transformational leaders act as role models for their followers. Since followers trust and admire their leaders, they emulate and internalize their leader's values. According to Pillai (Guns, 2020), transformational leadership encompasses many dimensions, including characteristics that foster charismatic actions, inspire inspiring motivation, provide intellectual stimulation, and pay attention to each person.

\section{METHODS}

In Indonesia, a survey of the banking sector was conducted for this report. A total of 273 respondents from six different companies returned valid data, reflecting an 88 percent response rate. 92 percent of the subjects had a college education or higher, 225 (81 percent) were male, and 50 (19 percent) were female. The mean age was 30, ranging from 20 to 48 years. The average lifespan was approximately three years, with approximately a quarter working less than three years and a third working more than ten years. Respondents hold a variety of jobs, including those in management, human resources, and marketing. Workers 
hold around $80 \%$ of work positions. This research used a four-part self-report questionnaire. The first segment, which comprises 50 items, includes statements about respondents' perceptions of organizational and creative environment influences. The second section includes elements that assess respondents' impressions of the learning culture's dimensions. There are 43 objects in all, and they span seven dimensions. The third segment includes items that assess respondents' expectations of the extent to which creativity is constructed. This structure comprises a total of 32 objects. Finally, the fourth segment requests respondents' biographical details.

The section that assesses organizational climate factors utilizes the (Ekvall and Ryhammar, 1999).-developed innovative climate questionnaire (CCQ, 1999). The ten CCQ factors are as follows: challenge/motivation; freedom; idea support; activeness/dynamism; fun/humor; debate; trust/openness; conflict; and risk-taking. To test participants' expectations of their supervisors' leadership actions, the $5 \mathrm{x}$ Multifactor Leadership Questionnaire (Bass and Avolio, 1995) was used. The following four subscales were used to measure transformational leadership: Ideal Influence (eight items), Inspirational Motivation (four items), Intellectual Stimulation (four items), and Individual Consideration (four items) (four items).

All variables in the sample were quantified using a seven-point Likert scale, with 1 indicating strong disagreement and 5 indicating strong agreement. The researchers used a condensed version of the multifactor leadership questionnaire (MLQ) (Avolio et al., 1999) to test respondents' responses to their leader's transformational leadership model. The MLQ consists of four items for each aspect of behavior: individual judgment, idealized control, intellectual stimulation, and inspirational motivation $(=0.94)$. Although the literature suggests that the TL construct is composed of four distinct components, in line with recent leadership research, we discovered a strong correlation between the four dimensions of transformational leadership, with a mean of 0.72. (Wang et al., 2014). It results in higherorder structures (Li et al., 2013).

The following table summarizes trial-based reliability estimates for each of the ten CCQ variables. (Ekvall and Ryhammar, 1999)defined the initial CCQ estimate (1999). Cronbach's coefficients for each CCQ factor obtained in this analysis were 0.92 for challenge/motivation, 0.74 for equality, 0.89 for support for ideas, 0.72 for activeness/dynamism, 0.72 for excitement/humor, 0.77 for discussion, 0.80 for trust/openness, and 0.72 for risk-taking (0.76). Time and dispute are omitted because they are believed to be expressed by other objects. The reliability of the 50 CCQ products as a whole was 0.96 .

\section{RESULTS}

Training starts with the external model and progresses to the internal model. The metrics used are only accurate for a limited period of time. The second command line for $\mathrm{X}$ and $\mathrm{Y}$ direction can be suppressed, but it is still considered in all output tabulations, not only in the diagram. The theory to be analyzed establishes a clear and positive link between transformational leadership style and an atmosphere conducive to innovation. The following are the formulations of the hypotheses that will be tested in this study: 
Ho $=$ There is no correlation between transformational leadership and an environment of innovation that is strong and constructive.

$\mathrm{HI}=$ Between transformational leadership and an innovative environment, there is a clear and positive correlation.

Ho is refused if the estimated T-count exceeds the T-table, and $\mathrm{HI}$ is accepted if the estimated T-count exceeds the T-table and vice versa. This test's reliability stage was $95 \%$, with a significance level of $\mathrm{a}=0.05$. Model for External Measurement Evaluation. The external model assessment is used to determine if the metrics used in the analysis are accurate and reliable. Tests are conducted to determine the validity of an indication that the build is legal to treat. The performance of the research validity test is depicted in the image below. Appendix 21 contains the output of the external load hypothesis 2. This display indicates that there are no load factors with values less than 0.5. Additionally, Appendix A5 contains the performance load associated with this hypothetical cross. The monitor indicates which indicator has the highest load factor for the construction being considered. It demonstrates the validity of the dimensions for assessing the relationship between the construct of transformational leadership and the environment of innovation.

A second approach for determining discriminant validity is to examine the square root of AVE, as illustrated in Table 1. Values greater than 0.5 are recommended. All of the constructs 5.17 of transformational leadership and the atmosphere of innovation have values greater than $0.5 \mathrm{AVE}$, as shown by the table display. It demonstrates that the instruction was correct, providing information about the intended construct. While Table 1 below illustrates the connection between latent variables.

Table 1. Correlation of Latent Variables Hypothesis 2

\begin{tabular}{lrrrrrrrrrrrrrrrr}
\hline & Y.A & Y.B & \multicolumn{1}{c}{ Y.C } & Y.D & Y.E & Y.F & Y.G & Y & Y.H & X.A & X.B & X.C & X.D & X.E & X & X.F \\
\hline Y.A & 1 & & & & & & & & & & & & & & \\
Y.B & 0.06 & 1 & & & & & & & & & & & & & \\
Y.C & 0.03 & -0.04 & 1 & & & & & & & & & & & & \\
Y.D & 0.03 & -0.02 & 0.31 & 1 & & & & & & & & & & & \\
Y.E & 0.78 & 0.22 & -0.01 & 0.13 & 1 & & & & & & & & & & \\
Y.F & 0 & -0.11 & 0.2 & 0.32 & 0.08 & 1 & & & & & & & & & \\
Y.G & 0.05 & 0.12 & 0.53 & 0.47 & 0.11 & 0.49 & 1 & & & & & & & & \\
Y & 0.21 & 0.07 & 0.53 & 0.74 & 0.33 & 0.6 & 0.79 & 1 & & & & & & & \\
Y.H & 0.01 & 0.07 & 0.3 & 0.51 & 0.14 & 0.45 & 0.57 & 0.84 & 1 & & & & & & \\
X.A & 0.3 & 0.16 & -0.03 & -0.01 & 0.28 & -0.06 & 0.03 & 0 & -0.12 & 1 & & & & & \\
X.B & 0.35 & 0.12 & -0.07 & 0.09 & 0.37 & 0.11 & 0.05 & 0.13 & 0 & 0.6 & 1 & & & & \\
X.C & 0.46 & -0.04 & 0.09 & 0.18 & 0.42 & -0.09 & 0.03 & 0.15 & -0.02 & 0.4 & 0.6 & & 1 & & & \\
X.D & 0.36 & 0.09 & -0.02 & 0.09 & 0.32 & -0.01 & 0.06 & 0.11 & 0.01 & 0.48 & 0.78 & 0.58 & 1 & & \\
X.E & 0.27 & 0.13 & 0.08 & 0.35 & 0.28 & 0.22 & 0.28 & 0.37 & 0.25 & 0.27 & 0.5 & 0.27 & 0.53 & 1 & \\
X & 0.46 & 0.08 & 0.05 & 0.18 & 0.44 & 0.02 & 0.11 & 0.21 & 0.05 & 0.67 & 0.9 & 0.81 & 0.87 & 0.56 & 1 \\
X.F & 0.05 & 0.02 & 0.23 & 0.29 & 0.09 & 0.2 & 0.37 & 0.41 & 0.4 & 0.09 & 0.1 & -0.05 & 0.07 & 0.52 & 0.2 & 1 \\
\hline
\end{tabular}

The following table shows the amount of validity and reliability of hypothesis 1 . AVE $=0.516$ for the build $\mathrm{X}$ (transformational leadership); thus, V0.516 $=0.718$. While the relationship between $\mathrm{Xi}$ (transformational leadership) and the other dimensions is 0.509 (Y 
$=$ environment of creativity), 0.404 (YA = challenge/motivation), 0.365 (YB = playful/humorous), 0.532 (supporting the concept of $\mathrm{YC}=$ ), ( $\mathrm{YD}=$ lateral cooperation), (YE $=$ freedom $),(\mathrm{YF}=$ risk taking $),(\mathrm{YG}=$ activity/dynamism $)$, and $(\mathrm{YH}=$ debate. This indicates that discriminant validity is satisfied. Reliability testing is conducted by examining the reliability value of the composite indicator, which tests the beam build. Reliability test results greater than 0.7 show a high degree of value. Table 1 shows the composite reliability's performance value. The performance results are shown for all constructs with a value greater than 0.7 , indicating that all constructs in the model meet the discriminant validity criterion.

The $\mathrm{R}$ Square for the variable $\mathrm{Y}=0.2423$ in Table 2, indicating that $\mathrm{Xi}$ (transformational leadership) can account for 24.23 percent of the variation in Y. (climate creativity). Meanwhile, GOF is calculated by multiplying the square root of the square $\mathrm{R}$ by the square root of the mean value of communality $=\mathrm{VR} 2 \times \mathrm{V}$ communality $=\mathrm{V} 0.7998 \times$ $\mathrm{V} 0.6590=05270$. T XI to $\mathrm{Y}$ is 2.0206 , which is more important than the T Table value of 1.96, as shown in Table 3. Thus, $\mathrm{X} \mid$ (transformational leadership) has a huge influence on $\mathrm{Y}$. (climate creativity). According to the original sample, the equation is as follows: $\mathrm{Y}=$ $0.2058 \mathrm{Xi}$. Another possible value for $\mathrm{T}$ is that it is one of the dimensional structures used to demonstrate important values.

Table 2. Average Variance Extracted (AVE), Composite Reliability, Cronbachs Alpha dan R Square Hypothesis 2

\begin{tabular}{lccccc}
\hline & AVE & $\begin{array}{c}\text { Composite } \\
\text { Relaibility }\end{array}$ & R Square & $\begin{array}{c}\text { Cronbachs } \\
\text { Alpha }\end{array}$ & Communality \\
\hline Y.A & 0.8508 & 0.9192 & 0.045 & 0.8358 & 0.8508 \\
Y.B & 0.7589 & 0.8628 & 0.0054 & 0.6842 & 0.7589 \\
Y.C & 0.9344 & 0.9661 & 0.2847 & 0.9298 & 0.9344 \\
Y.D & 0.855 & 0.9465 & 0.548 & 0.9154 & 0.855 \\
Y.E & 0.7217 & 0.9117 & 0.111 & 0.8698 & 0.7217 \\
Y.F & 0.8188 & 0.9003 & 0.3624 & 0.783 & 0.8188 \\
Y.G & 0.5092 & 0.7562 & 0.6191 & 0.5172 & 0.5092 \\
Y & 0.246 & 0.8601 & 0.2423 & 0.839 & 0.246 \\
Y.H & 0.6681 & 0.9092 & 0.7122 & 0.8742 & 0.6681 \\
X.A & 0.7958 & 0.8863 & 0.4468 & 0.7456 & 0.7958 \\
X.B & 0.5186 & 0.8108 & 0.8015 & 0.6901 & 0.5186 \\
X.C & 0.6264 & 0.9079 & 0.6482 & 0.8753 & 0.6264 \\
X.D & 0.5753 & 0.8703 & 0.7549 & 0.8131 & 0.5753 \\
X.F & 0.457 & 0.7023 & 0.3129 & 0.5885 & 0.457 \\
X & 0.2846 & 0.8936 & 0 & 0.8771 & 0.2846 \\
X.G & 0.9238 & 0.9732 & 0.0402 & 0.9588 & 0.9238 \\
Total average & & & & 0.7998 & 0.659 \\
\hline
\end{tabular}


Table 3. test of $T$ count

\begin{tabular}{lccccc}
\hline & $\begin{array}{c}\text { Original } \\
\text { Sample } \\
(\mathbf{O})\end{array}$ & $\begin{array}{c}\text { Sample } \\
\text { Mean (M) }\end{array}$ & $\begin{array}{c}\text { Standard } \\
\text { Deviation } \\
\text { (STDEV) }\end{array}$ & $\begin{array}{c}\text { Standard } \\
\text { Error } \\
\text { (STERR) }\end{array}$ & $\begin{array}{c}\text { T Statistics } \\
(\text { O/STERR) }\end{array}$ \\
\hline $\mathrm{Y} \rightarrow$ Y.A & 0.2122 & 0.2266 & 0.104 & 0.104 & 2.04 \\
$\mathrm{Y} \rightarrow$ Y.B & 0.0735 & 0.0875 & 0.0565 & 0.0565 & 1.2999 \\
$\mathrm{Y} \rightarrow$ Y.C & 0.5336 & 0.5351 & 0.0535 & 0.0535 & 9.9828 \\
$\mathrm{Y} \rightarrow$ Y.D & 0.7403 & 0.735 & 0.0341 & 0.0341 & 21.7295 \\
$\mathrm{Y} \rightarrow$ Y.E & 0.3332 & 0.3375 & 0.123 & 0.123 & 2.7095 \\
$\mathrm{Y} \rightarrow$ Y.F & 0.602 & 0.5974 & 0.0377 & 0.0377 & 15.9672 \\
$\mathrm{Y} \rightarrow$ Y.G & 0.7869 & 0.7844 & 0.0266 & 0.0266 & 29.5441 \\
$\mathrm{Y} \rightarrow$ Y.H & 0.8439 & 0.8397 & 0.0261 & 0.0261 & 32.3388 \\
$\mathrm{X} \rightarrow$ Y & $\mathbf{0 . 2 0 5 8}$ & $\mathbf{0 . 1 9 4}$ & $\mathbf{0 . 1 0 1 8}$ & $\mathbf{0 . 1 0 1 8}$ & $\mathbf{2 . 0 2 0 6}$ \\
$\mathrm{X} \rightarrow \mathrm{X} . \mathrm{A}$ & 0.6684 & 0.6701 & 0.0272 & 0.0272 & 24.6122 \\
$\mathrm{X} \rightarrow \mathrm{X} . \mathrm{B}$ & 0.8953 & 0.894 & 0.0111 & 0.0111 & 80.7682 \\
$\mathrm{X} \rightarrow \mathrm{X} . \mathrm{C}$ & 0.8051 & 0.8061 & 0.0361 & 0.0361 & 22.304 \\
$\mathrm{X} \rightarrow \mathrm{X} . \mathrm{D}$ & 0.8688 & 0.8688 & 0.0142 & 0.0142 & 61.2764 \\
$\mathrm{X} \rightarrow \mathrm{X} . \mathrm{E}$ & 0.5593 & 0.5659 & 0.0361 & 0.0361 & 15.5096 \\
$\mathrm{X} \rightarrow \mathrm{X} . \mathrm{F}$ & 0.2005 & 0.1904 & 0.1084 & 0.1084 & 1.8504 \\
& & & & &
\end{tabular}

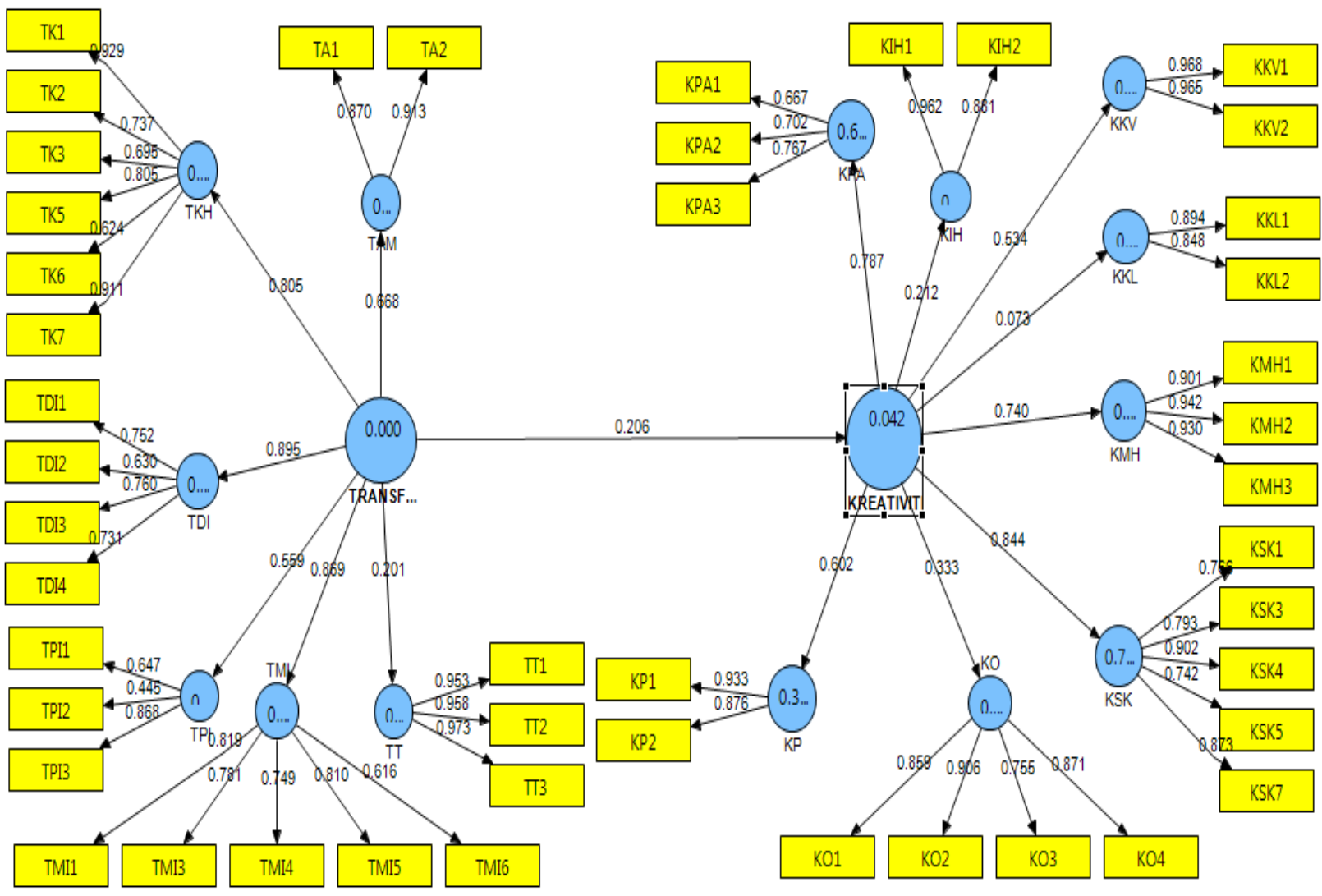

Figure 1. Full Model SEM Test Using Smart PLS 
The numbers in the image above represent the result of the T calculation. As a result, this statistic can be used as a validity check as well, as each indicator contributes an average value of 1.96 to the intended construct. Formula 1 for hypothesis testing: As demonstrated by the contribution of the study results in the table $r=0.2058$, there is a strong correlation between transformational leadership and an environment of innovation. Transformational Leadership (X) can account for 24.34 percent of the variance in the atmosphere of the innovation component (Y). There is a strong correlation between transformational leadership style (X) and the atmosphere of innovation (Y). As shown by the T-test output of 2.0206, this value is more meaningful than the T-table value of 1.96, with a significance level of 0.05 . The regression equation between transformational leadership and creativity climate is $\mathrm{Y}=0.2058$, which indicates that each level of change in the transformational leadership variable results in a 0.2058 increase in the creativity climate variable.

\section{DISCUSSION}

According to the findings of this study's review, there is a strong and positive relationship between the transformational leadership style variable and the atmosphere of innovation in the workplace on a superficial basis. Correlation test results indicated a value of 0.31 . It demonstrates that to improve the atmosphere for innovation in the workplace, the leadership position must be transformed. This finding is consistent with previous research conducted by (Redmond et al., 1993), which found that leaders who provide room and demonstrate appreciation for their subordinates' creative potential foster an environment conducive to employee creativity. Leaders must actively stimulate and motivate their subordinates to take risks in carrying out and completing their tasks. Additionally, prior empirical research indicates that leadership impacts the atmosphere of innovation (Kazama et al., 2002). According to (Nystrom's, 1990) study, transformational-style leaders significantly impacted an innovative environment in many companies and organizations in Sweden. Leaders constantly provide resources and motivation for their subordinates to cultivate and use their innovative abilities to support their job duties. According to (Nystrom's, 1990) model, transformational leadership can influence the creative environment both directly and indirectly through its control and power over the course and management of creative potential. The findings of this study provide compelling evidence that transformational leadership and an innovative environment have a positive effect on organizational success.

A business will prosper if its work environment fosters an environment conducive to innovation. The effectiveness of a company is inextricably linked to its strategy of providing opportunities for workers to exercise and improve their creative abilities in support of their work activities. As a result, a leader's position is critical in fostering and improving his subordinates' creative potential. Leaders are not only concerned with profit maximization; they must also be able to identify and grow their subordinates' innovative capacity to contribute positively to the organization. According to (Amabile et al., 2004), a leader's conduct is critical in deciding the evolution of the work setting, specifically the climate of innovation among employees. While the study's findings indicate that transformational leadership affects the atmosphere of innovation, this research can be expanded by examining transactional leadership styles or an individual's creative abilities. This research empirically 
confirms employees' expectations of how their leaders lead, the environment of supporting creativity, and their desire to perform creatively influence their creative output. According to recent research (Wang et al., 2014) transformational leaders foster ingenuity in their subordinate workers. Adding to (Gupta et al., 2013), this research discovered a strong correlation between transformational leadership and individual innovation. Consistent with (Gumusluoglu et al., 2013), this study's findings lend empirical support to the notion that transformational leadership is best rooted in collectivist culture (Gumusluoglu et al., 2013). Thus, by demonstrating transformational leadership in a collaborative environment, leaders will provide the help, assistance, consideration, and guidance that their subordinates constantly seek from them (Sinha, 2008). Additionally, it has been shown that followers who develop a personal relationship with their supervisor are more likely to demonstrate loyalty and respect (Howell and Shamir, 2005). Traditionally, subordinates prefer contingent personal relationships with their supervisors in group settings such as India (Sinha, 2008). Although taking into account the unique needs of each subordinate (individual considerations), a transformational leader develops positive personal relationships.

Transformational leaders exercise boss-only executive power. They also hold a source of virtue where subordinates may depend on their personal needs, such as teaching coaching to be imaginative (Bass et al., 2003). Consequently, the results of this study expand on the notion that leader-subordinate ties in India are governed by reverence and compassion (Sinha and Sinha, 1990). Transformational leaders may gain admiration and appreciation from their subordinates, which helps extract their subordinates' innovative output. Also, this research finds empirical evidence for group innovation climate cross-level control in deciding employee innovative behavior. Like (Wang et al., 2014) the results empirically confirm our prediction that the group's innovation environment is positively linked to employee creativity. We also found a significant mediating position between transformational leadership and employee imagination in the innovation environment. Thus, this study shows that transformative leaders will more efficiently engage their subordinates in innovative activity if their subordinates consider their organization's favorable environment for innovation. It confirms individuals perform better under change leaders in terms of creativity when they feel adequate support for innovation in resource access, encouragement, and appreciation. Evidence of the group's cross-level impact on climate innovation also confirms the group's consensus on acceptable behavior trends and mutual expectations of a positive innovation climate puts excellent pressure on participants to preserve unity (Dragoni, 2005) and enhances their motivation. Instrumental funding for individual artistic endeavors. This research also confirms that group membership substantially impacts individual attitudes and behaviors (Wang et al., 2014); (Hon et al., 2013), so individual variables cannot be analyzed alone without considering group results.

\section{CONCLUSION}

Finally, this research looks at the importance of transformational leadership in promoting a culture of innovation in the workplace. This study provides input for organizations or businesses to change their practices and work environment so that their organizations and superiors benefit workers. Use their imaginative ability to enhance their 
results. Hotel managers need to design training programs and customer counseling sessions to contact staff to work creatively. There are some drawbacks to this analysis that should be highlighted. First, since this analysis is survey-based and cross-sectional, it is difficult to explain the causal relationship between various research variables. As a result, future studies should take a longitudinal approach to investigate the impact of evolving transformational leadership styles on the environment of innovation in the workplace. Furthermore, when evaluating the hypothesized model, this study does not take various cultural factors into account. As a result, future research could gain deeper insights from comparative studies of individualistic and collectivistic samples. Furthermore, it is essential to replicate in other sectors on a larger and more diverse scale. Future research can also be undertaken to understand better other factors that can encourage employees to improve employee innovative behavior. The following suggestions for future research are made to address the study's shortcomings or limitations: Further research is anticipated to enable trials in the field of education services such as schools or universities, as the world of education in Indonesia requires transformational leaders and creative and innovative educators. Additionally, additional research is expected to incorporate not only transformational leadership variables and a climate of creativity but also other critical variables, such as job satisfaction or performance.

\section{REFERENCES}

Amabile, T. M., Collins, M. A., Conti, R., Phillips, E., Picariello, M., Ruscio, J., and Whitney, D. (2018). Creativity in context: Update to the social psychology of creativity. Routledge.

Amabile, T. M., Mueller, J. S., Simpson, W. B., Hadley, C. N., Kramer, S. J., and Fleming, L. (2002). Time pressure and creativity in organizations: A longitudinal field study.

Amabile, T. M., Schatzel, E. A., Moneta, G. B., and Kramer, S. J. (2004). Leader behaviors and the work environment for creativity: Perceived leader support. The Leadership Quarterly, 15(1), 5-32.

Aprilliyani, R. (2006). Pengaruh Kreativitas karyawan terhadap pengembangan Inovasi Baru Bagi Perusahaan. Fokus Ekonomi: Jurnal Ilmiah Ekonomi, 1(1), 31-37.

Asbari, M., Purba, J. T., Hariandja, E. S., dan Sudibjo, N. (2021). Membangun Kesiapan Berubah dan Kinerja Karyawan: Kepemimpinan Transformasional versus Transaksional. Jurnal Ilmiah Manajemen Dan Bisnis, 22(1), 54-71.

Azliyanti, E., Jadmiko, P., dan Utami, W. (2019). Peran Pemediasi Efikasi Diri Kreatif Pada Hubungan Antara Persepsi Terhadap Kepemimpinan Transformasional Pada Kreativitas Karyawan. Relevance: Journal of Management and Business, 2(2), 347356.

Bandura, A. (2002). Social cognitive theory in cultural context. Applied Psychology, 51(2), 269-290.

Bass, B. M. (1995). Comment: Transformational leadership: Looking at other possible antecedents and consequences. Journal of Management Inquiry, 4(3), 293-297.

Bass, B. M., Avolio, B. J., Jung, D. I., and Berson, Y. (2003). Predicting unit performance by assessing transformational and transactional leadership. Journal of Applied Psychology, 88(2), 207-218. 
Chen, G., Farh, J.-L., Campbell-Bush, E. M., Wu, Z., and Wu, X. (2013). Teams as innovative systems: Multilevel motivational antecedents of innovation in R\&D teams. Journal of Applied Psychology, 98(6), 1018.

Cooke, R. A., and Rousseau, D. M. (1988). Behavioral norms and expectations: A quantitative approach to the assessment of organizational culture. Group \& Organization Studies, 13(3), 245-273.

Ekvall, G., and Ryhammar, L. (1999). The creative climate: Its determinants and effects at a Swedish university. Creativity Research Journal, 12(4), 303-310.

Gong, Y., Huang, J.-C., and Farh, J.-L. (2009). Employee learning orientation, transformational leadership, and employee creativity: The mediating role of employee creative self-efficacy. Academy of Management Journal, 52(4), 765-778.

Guns, Stevens, MD. (2020). Transformational Leadership :A Closer Look at the Effects of Transformational Leadership. Harvard Medical School.

Gupta, V., and Singh, S. (2013). How leaders impact employee creativity: A study of Indian R\&D laboratories. Management Research Review.

Herrmann, D., and Felfe, J. (2013). Moderators of the relationship between leadership style and employee creativity: The role of task novelty and personal initiative. Creativity Research Journal, 25(2), 172-181.

Hon, A. H. Y. (2012). When competency-based pay relates to creative performance: The moderating role of employee psychological need. International Journal of Hospitality Management, 31(1), 130-138.

Hunter, S. T., Bedell, K. E., and Mumford, M. D. (2007). Climate for creativity: A quantitative review. Creativity Research Journal, 19(1), 69-90.

Jung, D. D., Wu, A., and Chow, C. W. (2008). Towards understanding the direct and indirect effects of CEOs' transformational leadership on firm innovation. The Leadership Quarterly, 19(5), 582-594.

Jung, D. I. (2001). Transformational and transactional leadership and their effects on creativity in groups. Creativity Research Journal, 13(2), 185-195.

Kazama, S., Foster, J., Hebl, M., West, M., and Dawson, J. (2002). Impacting climate for innovation: Can CEOs make a difference. 17th Annual Conference of the Society for Industrial and Organizational Psychology, Toronto, Canada, 1-26.

Khasanah, I. F. N., dan Himam, F. (2018). Kepemimpinan transformasional kepribadian proaktif dan desain kerja sebagai prediktor perilaku kerja inovatif. Gadjah Mada Journal of Psychology (Gamajop), 4(2), 143-157.

Makena, J. E. (2017). Pengaruh Kepemimpinan Transformasional Terhadap Kinerja Organisasi Melalui Pembelajaran Organisasi dan Inovasi Pada Hotel Prama Sanur Beach Bali. Jurnal Ekonomi \& Bisnis JAGADITHA, 4(2), 76-88.

Masro'in, B. (2020). Pengaruh Kepemimpinan Transformasional Terhadap Kreativitas Karyawan Melalui Innovation Climate Sebagai Variabel Mediasi Dan Creative SelfEfficacy Sebagai Variabel Moderasi Pada Karyawan PT. Sentra Vidya Utama. Universitas Airlangga.

Mustika, M. S. (2017). Pengaruh Kepribadian Proaktif pada Kreativitas Karyawan dengan Kepemimpinan Transformasional dan Autonomi Kerja sebagai Variabel Pemoderasi. Jurnal Bisnis Darmajaya, 3(2), 126-145.

Nardo, R., Evanita, S., \& Syahrizal, S. (2018). Pengaruh Kepemimpinan Transformasional, 
Dan Lingkungan Kerja Non Fisik Terhadap Perilaku Inovatif. JEBI (Jurnal Ekonomi Dan Bisnis Islam), 3(2), 209-215.

Nasir, M., Taufan, R. R., Fadhil, M., dan Syahnur, M. H. (2021). Budaya Organisasi Dan Disiplin Kerja Serta Pengaruhnya Terhadap Kinerja Karyawan. AkMen JURNAL ILMIAH, 18(1), 71-83.

Nieves, J., Quintana, A., and Osorio, J. (2014). Knowledge-based resources and innovation in the hotel industry. International Journal of Hospitality Management, 38, 65-73.

Ostrom, A. L., Bitner, M. J., Brown, S. W., Burkhard, K. A., Goul, M., Smith-Daniels, V., Demirkan, H., and Rabinovich, E. (2010). Moving forward and making a difference: research priorities for the science of service. Journal of Service Research, 13(1), 436.

Parker, C. P., Baltes, B. B., Young, S. A., Huff, J. W., Altmann, R. A., Lacost, H. A., and Roberts, J. E. (2003). Relationships between psychological climate perceptions and work outcomes: a meta-analytic review. Journal of Organizational Behavior: The International Journal of Industrial, Occupational and Organizational Psychology and Behavior, 24(4), 389-416.

Patterson, M., Warr, P., and West, M. (2004). Organizational climate and company productivity: The role of employee affect and employee level. Journal of Occupational and Organizational Psychology, 77(2), 193-216.

Setyowati, S., dan Etikariena, A. (2019). Peran Gaya Pemecahan Masalah dalam Hubungan Kepemimpinan Transformasional dengan Perilaku Kerja Inovatif. Jurnal Diversita, $5(2), 115-125$.

Shalley, C. E., and Gilson, L. L. (2004). What leaders need to know: A review of social and contextual factors that can foster or hinder creativity. The Leadership Quarterly, 15(1), 33-53.

Su-Yung, F. (2002). The Relationship Among Transformational Leadership, Organizational Commitment and Citizenship Bahavior: The Case of Expatriates. Master's Thesis. URN: etd0201101-153856.

Su'ud, M. (2000). Persepsi Sosial Tentang Kredibilitas Pemimpin. Sinergi Kajian Bisnis Dan Manajemen, 3(1), 51-65.

Sun, L.-Y., Zhang, Z., Qi, J., and Chen, Z. X. (2012). Empowerment and creativity: A crosslevel investigation. The Leadership Quarterly, 23(1), 55-65.

Wang, C.-J., Tsai, H.-T., and Tsai, M.-T. (2014). Linking transformational leadership and employee creativity in the hospitality industry: The influences of creative role identity, creative self-efficacy, and job complexity. Tourism Management, 40, 79-89.

Williams, F., and Foti, R. J. (2011). Formally developing creative leadership as a driver of organizational innovation. Advances in Developing Human Resources, 13(3), 279296.

Wulansari, R. C. (2016). Pengaruh Gaya Kepemimpinan Transformasional Terhadap Kreativitas Melalui Motivasi Intrinsik (Studi Pada Karyawan Divisi Produksi Pt. Dok Dan Perkapalan Surabaya Persero). Jurnal Ilmu Manajemen (JIM), 4(3), 1-10.

Zhou, J., and George, J. M. (2001). When job dissatisfaction leads to creativity: Encouraging the expression of voice. Academy of Management Journal, 44(4), 682696. 